\title{
The Effect of Financial Performance and Bank Size on Banking Stock Prices
}

\author{
Eni Wuryani ${ }^{*}{ }^{*}$, Susi Handayani ${ }^{1}$, Mariana ${ }^{1}$ \\ ${ }^{1}$ Universitas Negeri Surabaya, Surabaya, Indonesia \\ ${ }^{*}$ Corresponding author. Email: eniwuryani@unesa.ac.id
}

\begin{abstract}
Banking is the primary economic sector that serves as an intermediary. The purpose of this research is to assess the impact of financial performance and bank size on the stock price of banking institutions in 2019-2020. The variables to be analyzed in financial performance including profitability, liquidity, and capital sufficiency. The stock price is the dependent variable. Secondary data was collected for this study in the form of 86 data points derived from 43 financial statements of banks in Indonesia during a two-year period. Measurement of independent variables using ROA, LDR, CAR, and bank size. The research method used is a quantitative approach. This study uses regression analysis. The results showed that the variables of capital adequacy and bank size affected banking stock prices. While the profitability and liquidity, variables do not affect stock prices.
\end{abstract}

Keywords: Profitability, Liquidity, Capital, Adequacy, Bank Size, Stock Price.

\section{INTRODUCTION}

During the pandemic, the banking sector and capital market conditions in Indonesia were affected. The Composite Stock Price Index in Indonesia fell sharply and touched its lowest level at Rp.3,911.71. Financial performance in this study will use profitability, liquidity, and capital adequacy. Profitability will use Return on assets (ROA) as a measuring tool in research. Liquidity will use the Loan to Deposit Ratio (LDR) as a measuring tool in the study. Capital adequacy will use the Capital Adequacy Ratio (CAR) as a measuring tool in the study. Capital adequacy is a financial performance that assesses a bank's ability to guarantee its activities with sufficient capital. The ratio to determine capital adequacy used in this study is the Capital Adequacy Ratio (CAR). Banks that have good capital adequacy will increase investor confidence to invest so that stock prices increase. [1],[2]

The capacity of a bank to satisfy its short-term commitments is referred to as liquidity. Bank liquidity ratios, such as the Quick ratio, Banking Ratio/Loan to Deposit Ratio (LDR), and Loan to Assets Ratio, can be used to assess liquidity. The capacity of a reputable bank to pay its debts instills trust in the public, causing stock values to rise. In this study, the size of the bank is determined by the total assets possessed by the bank. Assets are an important component of a bank. A bank with a larger asset size is more profitable than a bank with a small asset size because a larger bank has a higher level of efficiency[3].

[4]-[12] have conducted research on the size of banks. The scale of a company has a beneficial impact on stock prices. The size of the bank (size) has an impact on the stock price and is significant (closing price). Because investors are more interested in stocks from banks with a positive public image, such as stable asset values, high bank values, low debt values, and a positive image. According to [13], the results showed that the size of the bank had a positive impact on stock prices. The logical relationship is that the size of the bank in terms of the total assets controlled by the bank will be able to send a signal to investors and potential investors.

H1: The size of the bank affects the stock price of the bank

According to [14] financial performance influences stocks. ROA has a positive and significant effect on stock prices. According to [15], ROA will generate profits if 
the management of assets in the bank is efficient. [16] and [17] Accurate bank performance measurement can use ROA. ROA can be used to measure the annual average of assets. ROA is used as a measure of the performance of a banking bank, the higher the ROA value, the better the performance of the bank, especially financial. ROA is the ratio between profit before tax and total assets. According to [18] ROA is the ratio between operating/operating profit to total assets. The calculation of ROA uses operating income because if using net income, it is feared that there will be an effect of non-operating income (expenses) that are not derived from the core business. The ROA ratio is very important, considering that the profits obtained from asset users can reflect the level of efficiency of a bank. The higher the ROA value can attract investors to invest in the bank. [12] explains that profitability (ROA) does not affect stock prices (closing price). Investors in buying shares do not only refer to bank profitability but there is a possibility that investors survey the company's image in the community.

$\mathrm{H} 2$ : Profitability affects stock prices

Liquidity to shares

Research related to bank liquidity has been widely studied by $[4,5,19,20]$. Short-term liabilities are bank capabilities that must be met, this can be measured by LDR (Loan to Deposit Ratio)

LDR is obtained from the distribution of loans and thirdparty funds. Third-party funds include demand deposits, savings, and time deposits. According to [1] LDR has a significant effect on stock prices. According to [2,3], LDR does not affect stock prices.

H3: Liquidity affects stock prices

Adequacy of Capital on stock prices

According to [16] financial performance influences stocks. CAR and ROA have a positive and significant effect on stock prices while LDR has a negative and significant effect on stock prices. CAR reflects the bank's ability to cover the decline in assets due to losses on bank assets by using their capital. Sufficient capital not only prevents the occurrence of bank failure but operating losses and investment losses must be immediately covered with sufficient profits if the bank is to survive. CAR is the ratio of capital to Risk-Weighted Assets (RWA). The minimum CAR for each bank following the standards set by the Bank for International Settlements (BIS) is $8 \%$. Banking banks listed on the Indonesia Stock Exchange have included RWA in their financial statements. According to [2,3] does not affect stock prices.

H4: Capital adequacy affects stock prices

\section{RESEARCH METHOD}

This research is a type of quantitative research to analyze financial performance and stock prices. The criteria for determining the sample in this study are as follows: (1) IDX-listed banking banks in 2019 - 2020 and (2) Complete stock price information is available and can be accessed on the website https://rti.co.id/. The method used in the data collection technique is the documentation method.

The multiple regression model equation is:

$Y_{1}=a+b X_{1}+b X_{2}+b X_{3}+b X_{4}+b X_{5}+e$

Information:

$\mathrm{a}=$ Constant Variable

$\mathrm{b}=$ Coefficient of direction

$\mathrm{X}_{1}=$ Bank Size

$\mathrm{X}_{2}=\mathrm{ROA}$

$\mathrm{X}_{3}=\mathrm{LDR}$

$\mathrm{X}_{4}=\mathrm{CAR}$

$\mathrm{Y}_{1}=$ Stock Price

$\mathrm{e}=$ error

\section{ANALYSIS RESULTS}

\subsection{Normality test}

The Kolmogorov - Smirnov (K-S) non-parametric statistical test was utilized in this work to determine residual normality. The fact that the Kolmogorov Smirnov value in Table 1 is 0.080 and significant at 0.200 indicates that the residual data is regularly distributed.

Table 1. Test of Normality

\begin{tabular}{|l|l|c|}
\hline \multicolumn{2}{|l|}{ Information } & \multicolumn{2}{|l|}{$\begin{array}{l}\text { Unstanfardized } \\
\text { Residual }\end{array}$} \\
\hline $\mathrm{N}$ & 86 \\
\hline $\begin{array}{l}\text { Normal } \\
\text { Parameter }\end{array}$ & Mean & 0,000 \\
& & \\
\cline { 2 - 3 } & $\begin{array}{l}\text { Std. } \\
\text { Deviation }\end{array}$ \\
\hline & Absolute & 0,485 \\
\cline { 2 - 3 } & Positif & 0,80 \\
\cline { 2 - 3 } & & 0,62 \\
\hline Test Statistic & $-0,080$ \\
\hline \multicolumn{2}{|l|}{ Asymp. Sig. (2-tailed) } & 0,080 \\
\hline
\end{tabular}

a. The distribution of the test results is normal.

b. Derived from data.

c. Lilliefors Significant Adjustment.

\subsection{Autocorrelation Test}

The autocorrelation test on the endogenous variable of stock prices shows the Durbin Watson (DW) value of 1.812. The value of the Durbin Watson (DW) 
table with the number of $\mathrm{n}=86$ and the independent variable $4(\mathrm{k}=4) \mathrm{dl}$ of $1.5536 \mathrm{du}$ of 1.7478 . The condition that there is no autocorrelation either positive or negative is $\mathrm{dl}<\mathrm{DW}<4-\mathrm{du}$. The results of the autocorrelation test showed $1.5536<1.812<2.4464$. So it can be concluded that there is no autocorrelation either positive or negative.

Table 2. Autocolleration Test

\begin{tabular}{|c|c|c|}
\hline Model & Std. The error of the Estimate & Durbin-Watson \\
\hline 1 & 0,49636 & 1,812 \\
\hline
\end{tabular}

a. Predictors: (Constant), CAR, LDR, ROA, SIZE

b. Dependent Variable: Saham

\subsection{Multicollinearity Test}

The test results in Table 3 show that the tolerance value is more than 0.10 and the VIF is not greater than 10 . Therefore, the test results of this model meet the assumptions of the recursive model. It is possible to conclude that this model lacks multicollinearity between independent variables in the regression model.

Table 3. Multicolonerity Test

\begin{tabular}{|l|c|c|}
\hline Independent Variable & Tolerance & VIF \\
\hline SIZE & 0,615 & 1,625 \\
\hline ROA & 0,817 & 1,224 \\
\hline LDR & 0,908 & 1,101 \\
\hline CAR & 0,712 & 1,404 \\
\hline
\end{tabular}

\subsection{Heteroscedasticity Test}

The heteroscedasticity test used the Glacier test, by regressing the independent variable with the absolute residual value. Table 4 shows a significance value of more than 0.05 , so it is concluded that there is no heteroscedasticity in the regression model.

Table 4. Heterocedasticity Test

\begin{tabular}{|l|c|c|}
\hline $\begin{array}{l}\text { Variabel } \\
\text { Independent }\end{array}$ & Tolerance & Significant \\
\hline SIZE & $-0,148$ & 0,883 \\
\hline ROA & $-1,712$ & 0,091 \\
\hline LDR & $-1,228$ & 0,223 \\
\hline CAR & 1,804 & 0,075 \\
\hline
\end{tabular}

In Table 5, the determination test has an $\mathrm{R} 2$ value of $47.4 \%$ with a significance level of $<0.05$, This shows that the independent variable can predict the dependent variable 47.4 percent of the time.
Table 5 Determination Coeficient Test

\begin{tabular}{|c|c|c|c|}
\hline Model & R & R Square & Adjusted R Square \\
\hline 1 & 0,706 & 0,498 & 0,474 \\
\hline
\end{tabular}

a. Predictors: (Constant), CAR, LDR, ROA, SIZE

\subsection{Simultaneous Test (F Statistics Test)}

A simultaneous test is used to see how the independent factors interact with the dependent variable at the same time. A significance level of 0.005 was used in the F test of influential terms. Table 6 demonstrates that the variables CAR, LDR, ROA, and SIZE combined have a significance value of 0.000 , indicating that they have an impact on stock prices.

Table 6 Simultaneous Test

\begin{tabular}{|l|l|l|l|}
\hline \multicolumn{2}{|c|}{ Model } & Statistic F & Significant \\
\hline & & & \\
1 & Regression & 20,120 & 0,000 \\
\hline
\end{tabular}

a. Dependent Variable: PRICE

b. Predictors: (Constant), CAR, LDR, ROA, SIZE

\subsection{Partial Test (Statistical Test t)}

To determine the link between each independent variable and the dependent variable, a partial test is performed. The conditional t-test has a significance level of 0.005 for its effect. Table 7 shows that SIZE has a 0.000 significance level effect on stock prices and that the direction of the connection is positive, implying that the larger the bank, the higher the stock price. With a significance level of 0.127 , ROA has no effect on the stock price. With a significance level of 0.184 , LDR has no effect on the stock price. With a significance level of 0.000, CAR has an impact on stock prices, and the link is positive. The larger the CAR, the better.

Table 7. Partial Test Coefficients

\begin{tabular}{|c|c|c|c|c|}
\hline \multicolumn{2}{|c|}{ Model } & $\begin{array}{c}\text { St.Co- } \\
\text { efficient } \\
\text { Beta }\end{array}$ & Statistik T & $\begin{array}{c}\text { Signif } \\
\text { icant }\end{array}$ \\
\hline \multirow{1}{*}{1} & Constant & & $-4,781$ & 0,000 \\
\cline { 2 - 5 } & SIZE & 0,773 & 7,706 & 0,000 \\
\cline { 2 - 5 } & ROA & 0,134 & 1,543 & 0,127 \\
\cline { 2 - 5 } & LDR & $-0,111$ & $-1,340$ & 0,184 \\
\cline { 2 - 5 } & CAR & 0,426 & 4,574 & 0,000 \\
\hline
\end{tabular}

Dependent Variable: PRICE

The size of the bank affects the stock price, the greater the assets owned by the bank the higher the stock price. The ability of banks to manage bank assets will provide confidence to investors so that stock prices will rise. This study supports the research of [13] that stock price is 
affected by bank size. Stock price is not affected by profitability, this is because the profits earned by the bank are not optimal and unstable. In 2000, many banking profits decreased compared to 2019.

The stock price is not affected by liquidity, this shows the ability of banks to pay off obligations does not affect market prices. The results of this study support [3]. Capital adequacy affects stock prices because the greater the capital from the bank, the more confidence it gives investors to buy shares, so the demand for shares is higher and stock prices are increasing. This study does not support the research of $[2,3]$ that CAR does not affect stock prices.

\section{CONCLUSION}

Bank size and bank capital adequacy affect stock prices. Assets and capital owned by banks attract investors to buy shares so that the stock price will increase. Profitability and liquidity do not affect stock prices. The profit earned by the bank due to instability and the bank's ability to make debt payments that are not optimal cannot affect stock prices.

\section{ACKNOWLEDGMENTS}

We thank you because this article is the result of policy research from the Faculty of Economics and Business with the Rector's Decree 840/UN38/HK/PM/ $2 \mathrm{O} 21$

\section{REFERENCES}

[1] Satria Indra., Iha Haryani Hatta. (2015). Pengaruh kinerja keuangan terhadap harga saham 10 bank terkemuka diindonesia. Jurnal Akuntansi/Volume XIX, No.02 Mei 2015: 179-191.

[2] Fordian Dian, (2017) Pengaruh CAR, LDR, dan EPS terhadap Harga Saham (Studi pada Bank BUMN yang Listing di BEI Periode 2012 - 2016), Jurnal Bisnis Darmajaya, Vol.3 No.1, Januari 2017.

[3] Masril. (2018). Pengaruh CAR dan LDR terhadap Harga Saham pada Perbankan di Bursa Efek Indonesia, Jurnal Samudra Ekonomi dan Bisnis, Volume 9, NO 2.

[4] Abdullah, M. N., Parvez, K., Akther, S., \& Ayreen, S. (2014). Bank specific, industry-specific and macroeconomic determinants of commercial bank profitability: A case of Bangladesh. World Journal of Social Sciences, 4(3), 82-96. https://doi.org/10.18488/

journal.1006.2019.92.174.183.

[5] Farooq, M., Khan, S., Atique Siddiqui, A., Tariq Khan, M., \& Kamran Khan, M. (2021). Determinants of profitability: A case of commercial banks in Pakistan. Humanities \& Social Sciences Reviews, 9(2), 01-13. https://doi.org/10.18510/hssr.2021.921.

[6] Gaber, A. (2018). Determinants of banking sector profitability: Empirical evidence from Palestine. International Journal of Economics and Finance, 9(7), 60-68.

[7] Hashem, H. Y. (2016). Determinants of Egyptian banking sector profitability: Time-series analysis from 2004-2014. International Journal of Business and Economic Sciences Applied Research, 9(2), 73-78. https://doi.org/10.5539/ijef.v9n7p60.

[8] Hoffmann, P. S. (2011). Determinants of the profitability of the US banking industry. International Journal of Business and Social Science,2(22).http://www.ijbssnet.com /journals/ Vol_2_No_22_December_2011/30.pdf.

[9] Krishna Bimal, Shiu Lingam, Anjani Mala, Rajit S. (2021). Determinant of Bank Profitability: Empirical Evidence from a Pacific Small Island Developing State, Humanities \& Social Sciences Reviews, Vol 9, No 3, 2021, pp 16-29 https://doi.org/10.18510/hssr.2021.933.

[10] Kumar, V., Thrikawala, S., \& Acharya, S. (2021). Financial inclusion and bank profitability: Evidence from a developed market. Global Finance Journal, 100609.

https://doi.org/https://doi.org/10.1016/j.gfj.2021.10 0609.

[11] Rahman, M. M., Hamid, M. K., \& Khan, M. A. M. (2015). Determinants of bank profitability: Empirical evidence from Bangladesh. International Journal of Business and Management, 10(8). https://doi.org /10.5539/ijbm.v10n8p135

[12] Wijaya, Rico (2017) Kinerja Keuangan dan Ukuran Perusahaan terhadap Harga Saham dengan Kebijakan Dividen sebagai Variabel Intervening, Jurnal Keuangan dan Perbankan, 21(3): 459-472, 2017 Nationally Accredited: No.040/P/2014 http://jurnal.unmer.ac.id /index.php/jkdp

[13] Acheampong Prince, Evans Agalega, Albert Kwabena Shibu, (2014). The Effect of Financial Leverage and Market Size on Stock Returns on the Ghana Stock Exchange: Evidence from Selected Stocks in the Manufacturing Sector, International Journal of Financial Research Vol. 5, No. 1.

[14] Fahlevi, Rido Raiza ., Set Asmapane., Bramantika Oktavianti. (2018). Pengaruh kinerja keuangan terhadap harga saham pada perusahaan perbankan yang terdaftar di bursa efek indonesia, Akuntabel 15 
(1), $2018 \quad 39-48$ http://journal.feb.unmul.ac.id/ index.php/Akuntabel.

[15] Hassan, M. K., \& Bashir, A.H. M. (2012). Determinants of Islamic banking profitability. In Islamic Perspectives on Wealth Creation (Issue April 2014). https://doi.org/10.3366/edinburg h/9780748621002.003.0008

\{16] Khrawish, H. A. (2011). Determinants of commercial banks performance: evidence from Jordan. International Research Journal of Finance and Economics, 5(5), 19-45.

[17] Krishna Bimal, Shiu Lingam, Anjani Mala, Rajit S. (2021). Determinant of Bank Profitability: Empirical Evidence from a Pacific Small Island Developing State, Humanities \& Social Sciences Reviews, Vol 9, No 3, 2021, pp 16-29 https://doi.org/10.18510/hssr.2021.933.

[18] Samsul, Sandro Heston., Sri Murni., Johan R. Tumiwa. (2016). Pengaruh Kinerja Keuangan Perbankan terhadap Harga Saham Yang ditawarkan di Bursa Efek Indonesia (Studi Kasus 10 Bank Dengan Aset Terbesar). Jurnal Berkala Ilmiah Efisiensi Volume 16 No. 02.

[19] Godfrey, M. (2015). Liquidity and bank performance. International Business \& Economics Research Journal (IBER), 14(3), 453. https://doi.org/10.19030/iber.v14i3.9218.

[20] Hakimi, A., \& Zaghdoudi, K. (2017). Liquidity risk and bank performance: An empirical test for Tunisian banks. Business and Economic Research, 7(1), 46. https://doi.org/10.5296/ ber.v7i1.10524. 